\title{
IMPACT OF OPENNESS TO EXPERIENCE ON PROJECT SUCCESS WITH MEDIATING ROLE OF CREATIVITY AND MODERATING ROLE OF UNCERTAINTY AVOIDANCE
}

\author{
MARINA MAILK \\ Riphah International University, Islamabad, Pakistan
}

\begin{abstract}
The purpose of the study was to examine the impact of openness to experience on project success with the mediating role of creativity and moderating role of uncertainty avoidance. Data were collected from 100 project managers by using questionnaires. In order to analyze the relationship regression and correlation techniques were used, which indicated the positive impact of openness to experience on creativity. The results of study indicated positive and significant impacts of predictors on response variables.
\end{abstract}

\section{INTRODUCTION}

Around the world, managers face an important dilemma which is whether to continue allocating resources towards a project, if it's success is dubious. Often the amount of resources already employed may bias the managerial decisions towards letting the project continue. In the last 30 years, project success has generally been subjected to a lot of attention with regard to research in the area of project management (Ika, 2009; Pinto \& Slevin, 1988). With the evolution and maturity of our understanding regarding project success (Jugdev \& Müller, 2005), we have comprehended the intricacies and obscurities inherent in our ability to measure and define it (e.g. Baccarini, 1999; Fowler \& Walsh, 1999; Hyväri, 2006; Ika, 2009; Jugdev\& Müller, 2005; Thomas \& Fernandez, 2008). Project success is now regarded as a multidimensional construction with the availability of organized procedures, as well as commercial, communicative and strategic dimensions; although, it may not be obvious when measuring project success. (e.g. Bannerman, 2008; Cao \& Hoffman, 2011; Ika, 2009; Jugde v\& Müller, 2005; Jugdev, Thomas, \& Delisle, 2001; Shenhar, Dvir, Levy, \& Maltz, 2001; Thomas \& Fernandez, 2008).Success of project is often measured quantitatively as simple formula application is easy,and on the assumption that a universally determined criteria for success exists (Ika, 2009). Researchers classified that determination of project progress as success or failure remains challenging and knowledge of project management is not very consistent (Cicmil \& Hodgson, 2006). Subjective point of view is that project success is a social phenomenon and created by group of individuals
(Alderman \& Ivory, 2011; Ika, 2009; Packendorff, 1995).

Researchers have examined effects of project manager personality on project outcomes in diverse studies,studying personality and categories of projects (Dvir, Sadeh, \& Malach-Pines, 2006), leadership competencies (Geoghehan \& Dulewicz, 2008), specific personality traits such as conscientiousness and openness to experience (Thal \& Bedingfield, 2010), etc. Data available suggests that 5 -factor model of personality termed as the "Big Five" (Goldberg, 1990) covers all personality traits under its domain. It has been found to be identical across nearly all cultures (McCrae \& Costa, 1997; Pulver, Allik, Pulkkinen, \& Hamalainen, 1995; Salgado, 1997) and has remained fairly stable over the years (Costa \& McCrae, 1992a, 1988). The model is composed of neuroticism, extraversion, openness to experience, agreeableness, and conscientiousness. Current study focuses on examining openness to experience and how it affects project success.

Openness to experience is a key personality trait, particularly at the initiation of a project when team members search forinnovativeideas. Thiseventuallyleads the organization to be more innovative in its operations (Salge, Farchi, Barrett \& Dopson, 2013). Organizations appreciate innovativeness in their employees and try to instill it through training. Therefore, academics have conducted extensive research to examine the assessment and enhancement of an individual's innovative capabilities in terms of inventions, process and product innovations, technology innovation adoption and new product purchase (Goldsmith \& Foxall, 2003, Hyvonen \& Tuominen, 2006). In this research, creativity is perceived as the manifestation of creative output imitated in the 
result of the creative process carried out by individuals, in an innovative team environment (Woodman et al., 1993). Innovative initiatives by the workforce of an organization are an important basis of an organization's competitive advantage and drive its economic growth. Avoidance of uncertainty is the dismissal of obscurity with the goal of avoiding concerns, to the extent to which a person may feel comfortable in unprecedented situations. This represents fear of uncertain situations and a resistant attitude towards innovation (Steenkamp, Hofstede \& Wedel, 1999).

\section{REVIEW OF LITERATURE}

\section{Relationship between openness to experience and creativity}

Openness to experience is one of the factors of big five Factor Model (Costa \& McCrae, 1992), which captures that individuals are open minded, imaginative and original (McCrae, 1987). Project team members search for such innovative ideas that eventually lead the organization to be more innovative in its operations (Salge, Farchi, Barrett \& Dopson, 2013). Creativity is defined as production of new and hypothetically beneficial ideas and social context and can be seen in project outcomes (Shalley \& Zhou, 2008).

Openness to experience increases creativity in performance of employees and use of creativity supports intellectual processes (Zhou, 2003). The previous findings determined that openness to experience predicts creative outcomes and creative processes. Similarly, openness to experience is positively associated to project performance in problem solving producing creative ideas (Leung, Maddux, Galinsky \& Chiu, 2008). Openness to experience is positively related to creativity, in numerous domains (Feist, 1998). In organizational settings where there is a weak relation it suggested that impact of openness on creativity might vary in contextual terms (Andrews \& Smith, 1996; Burke \& Witt, 2002). Openness to experience has access to variety of experiences and perspectives; therefore, it results in creativity in project performance (McCrae \& Costa, 1997). Literature suggests that relationship between personal characteristics of openness to experience and creativity is universal (Heine \& Buchtel, 2009). Therefore, hypothesis one proposes:

\section{Hypothesis 1. Openness to experience positively associated with creativity.}

\section{Relationship between creativity and project success}

Projectsuccesshastwoconcepts:projectmanagement focusing on processes of projects, successful cost, time and quality management and project success dealing with successful outcome of product for which project was started according to needs of the people (Baccarini, 1999). Exploration of ideas is connected with increasing variance, experimentation, searching for alternatives and it is important for organizational learning as well as for the better outcome of project in form of success (March, 1991). Creativity indicates that self-confidence and consequent independency perceived by project team members help to enhance employee creativity, which will result in employee performance and project success (Barron \& Harrington, 1981).Creativity makes employees learn about the fundamental values, identity and motives or goals of the projects (Avolio and Gardner, 2005). Facilitation of tasks to employees makes sure to develop their expertise to perform well and produce an urge for creative work for project (Amabile, 1996).

Thus hypothesis two posits:

\section{Hypothesis 2. Creativity is positively associated with project success.}

\section{Relationship between openness to experience with project success}

People who score high on openness to experience are more explorative and have divergent thinking, which helps them use more creative ideas and outcomes in form of project success (DeYoung, Peterson, \& Higgins, 2005; McCrae, 1987). Openness to experience has higher connection with project success and its creative achievement for the organization and it also tends to individual differences (Carson, Peterson, \& Higgins, 2005). Openness to experiences produces creative process to increase cognitive flexibility in organizations and it also predicts individual creative capacity (Eysenck, 1995).

Therefore, hypothesis three was developed as follow:

\section{Hypothesis 3. Openness to experience is positively associated with project success.}

\section{Mediating role of creativity}

Creativity leads employees to focus on novel ideas which will be useful for the project of an organization to achieve goals. It motivates the employees to explore their interests, engage their curiosity (Mohrman, Gibson, \& Mohrman, 2001). Creativity increases the range of cognitive information available expands the scope towards set of ideas and identifies the patterns to encourage the employees to associates between 
ideas (Fredrickson, 1998). Creativity makes employees more flexible, willing to take risks and openness to experience reduces complexity, which in outcome expands their access to ideas and potential solution for their project success (Gagne' \& Deci, 2005). Cognitive process is such a process in which every person in an organization adopts others' opinions to understand the preferences, values and needs of the project to make it successful (Parker \& Axtell, 2001). Personal and contextual characteristics influence the creativity in the organization's individuals, personal characteristics include five factors of personality traits (Gough's, 1979) and contextual characteristics include job complexity, goals and deadlines, and physical work environment of an organization (Shalley \& Zhou, 2003).

In the long run, study of professionals working on project teams found that effective reactions characterized by satisfaction were positively associated with creativity (Staw, 1995). Creativity viewed as the key to successful implementation of creative ideas and also an important tool for the effectiveness of all kinds of projects in the organizations in short and long run (Oldham \& Cummings, 1996).

Hence,

Hypothesis 4. Creativity mediates the positive relationship between openness to experience and project success

\section{Moderating role of uncertainty avoidance}

Hofstede defined uncertainty avoidance as "the extent to which members of culture feel threatened by uncertain or unknown situations (Hofstede, 1991). The study identified uncertainty avoidance value varies across cultures. Uncertainty avoidance has been treated at collective cultural level (Albers-Miller \& Gelb, 1996), and as well as at an individual level as a personality trait (Singelis, 1994). Uncertainty avoidance builds the personality trait similar to tolerance to ambiguity in an organization. Employees try to avoid uncertainty in projects and those who score high on uncertainty avoidance are more likely to rely on decisions of the organization for project success (Triandis, 1995). Low uncertainty avoidance positively relates the creativity and project success and also advocates the higher level authorities. Hofstede suggested that collecting ideas in low uncertainty avoidance companies and then refining them into high uncertainty avoidance companies is characterized by accuracy and punctuality (Hofstede, 2001).

Hypothesis 5. Uncertainty avoidance positively moderates the relationship between creativity and project success.
THEORETICAL FRAMEWORK

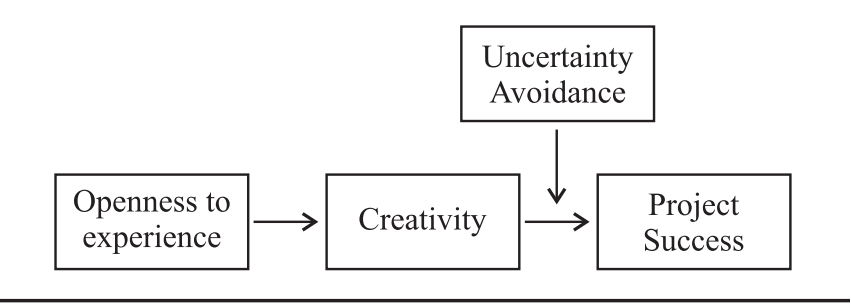

\section{RESEARCH METHODLOGY}

The purpose of this study is to examine the impact of openness to experience on project success with a mediating variable of creativity and moderating effect of uncertainty avoidance. It is a cross-sectional study with data collected using questionnaire method. Unit of analysis is individual. The target population in this study is employees in the project based organizations in the twin cities of Rawalpindi and Islamabad. For the purpose of drawing sample, convenient sampling technique was used due to the time and budget constraints. The sample for this research consists of employees from the project based organizations of Rawalpindi and Islamabad. A total of 110 self-administered questionnaires were floated in different organizations, 100 questionnaires were received back which were completed and could be utilized for the analysis purpose. The response rate came out to be $90 \%$. Respondents were assured of the data confidentiality and the interference of the researcher was minimum.

The responses indicated that $40 \%$ of the total respondents were male while the remaining $60 \%$ were female. $34 \%$ of the total respondents lied under the age group of $25-35,54 \%$ in the age group of $35-45,12 \%$ in the age group of 45-55. Education wise distribution of respondents showed that $2 \%$ of the total respondents were having the intermediate degree, $16 \%$ were having the graduation degree and the remaining $41 \%$ were having the master's degree and $32 \%$ were having Ms/ MPhil degree and 9\% were having $\mathrm{PhD}$ degree.

\section{Instrumentations}

Questionnaires used for the data collections were adopted from the previous researches. Questions were measured on a 5 point Likert scale where $1=$ strongly disagree, $2=$ disagree, $3=$ Neutral, $4=$ agree and $5=$ strongly agree.

\section{Openness to experience}

For openness to experience the scale used was 
adopted from Mowen, John C and Nancy Spears (1999). Scale consisted of 5 items, with the Cronbach's Alpha at 0.702 , validating the reliability of the scale.

\section{Project success}

In order to measure project success a 9-item scale was used by Belout, A., \& Gauvreau, C. (2004). The Cronbach's alpha value of the scale was measured at 0.683 .

\section{Creativity}

The scale used to measure creativity was adopted from Zhou, J., \& Oldham, G. R. (2001). It consisted of 13 items, with Cronbach's alpha at 0.861 .

\section{Uncertainty avoidance}

Uncertainty avoidance was measured using a 4-item scale, by Rai, Arun, Likoebe M. Maruping, and Viswanath Venkatesh (2009). The Cronbach's alpha = 0.672 .

\section{RESULTS}

The results and findings of this research study are discussed below. Analysis includes correlation and regression analysis. Hierarchical regression was also conducted to determine the impact of moderation and mediation.

TABLE 1

\section{Correlation Analysis}

\begin{tabular}{lcccc}
\hline \multicolumn{1}{c}{ Variables } & $\mathbf{1}$ & $\mathbf{2}$ & $\mathbf{3}$ & $\mathbf{4}$ \\
\hline $\begin{array}{l}\text { Openness to } \\
\text { experience }\end{array}$ & 1 & & & \\
Creativity & $.529^{* *}$ & 1 & & \\
Project success & $.269^{* *}$ & $.532^{* *}$ & 1 & \\
$\begin{array}{l}\text { Uncertainty } \\
\text { avoidance }\end{array}$ & $.283^{* *}$ & $.270^{* *}$ & $.426^{* *}$ & 1 \\
\hline
\end{tabular}

**. Correlation is significant at the 0.01 level (2-tailed).

Correlation analysis shows the relationship between variables openness to experience, creativity, uncertainty avoidance and Project Success. The correlation between openness to experience and creativity is $0.529^{* *}$, which indicates significant and positive correlation between both variables. The correlation between openness to experience and creativity is $0.269^{* *}$, which means there is positive correlation between both variables. Similarly, project success and creativity are also positively correlated at $0.532 * *$. Uncertainty avoidance and openness to experience are correlated at $0.283^{* *}$, which shows positive correlation between the variables. The correlation between uncertainty avoidance and creativity is $0.207^{* *}$, which ascertains a positive correlation between both variables; as well as the correlation between uncertainty avoidance and project success at $0.426^{* *}$.

TABLE 2

Hierarchical Regression Analysis

Predictor Outcome Project Success

\begin{tabular}{|c|c|c|c|}
\hline Step I & $\boldsymbol{\beta}$ & $\mathbf{R}^{2}$ & $\Delta \mathbf{R}^{2}$ \\
\hline Control Variables & .125 & .132 & $.132 * *$ \\
\hline \multicolumn{4}{|l|}{ Step II } \\
\hline Creativity & .527 & .387 & $.255^{* *}$ \\
\hline \multicolumn{4}{|l|}{ Step III } \\
\hline Openness to experience & .017 & .387 & .000 \\
\hline \multicolumn{4}{|c|}{$\begin{array}{l}\text { a. Predictors: (Constant), Education, Gender, Age } \\
\text { b. Predictors: (Constant), Education, Gender, Age, } \\
\text { C_Mean }\end{array}$} \\
\hline \multicolumn{4}{|c|}{$\begin{array}{l}\text { c. Predictors: (Constant), Education, Gender, Age, } C_{-} \\
\text {Mean, OE_Mean }\end{array}$} \\
\hline
\end{tabular}

Table (2) shows the results of the mediated regression analysis. The results indicate that although the direct relationship between openness to experience and project success is not significant, by incorporating the mediator, i.e. creativity, the change is $\mathrm{R}^{2}$ occurs at $0.255^{* *}$, which is significant, thus indicating that creativity mediates the relationship between openness to experience and project success, leading to the acceptance of hypothesis 4 .

TABLE 3

Results of Hierarchical Moderated Regression Analysis

\begin{tabular}{|c|c|c|c|}
\hline \multirow{2}{*}{$\begin{array}{l}\text { Predictor } \\
\text { Step I }\end{array}$} & \multicolumn{3}{|c|}{$\begin{array}{c}\text { Outcome } \\
\text { Project Success }\end{array}$} \\
\hline & $\boldsymbol{\beta}$ & $\mathbf{R}^{2}$ & $\Delta \mathbf{R}^{2}$ \\
\hline Control Variables & .125 & .132 & $.132 * *$ \\
\hline \multicolumn{4}{|l|}{ Step II } \\
\hline Openness to experience & $.185^{* *}$ & .284 & $.152 * *$ \\
\hline Uncertainty avoidance & $.321 * *$ & - & - \\
\hline \multicolumn{4}{|l|}{ Step III } \\
\hline OExUA & .969 & .295 & .011 \\
\hline \multicolumn{4}{|c|}{ a. Predictors:(Constant),Education, Gender, Age } \\
\hline \multicolumn{4}{|c|}{$\begin{array}{l}\text { b. Predictors:(Constant),Education, Gender, Age, UA_ } \\
\text { Mean, OE_Mean }\end{array}$} \\
\hline \multicolumn{4}{|c|}{$\begin{array}{l}\text { c. Predictors:(Constant),Education, Gender, Age, UA } \\
\text { Mean, OE_Mean, OExUA }\end{array}$} \\
\hline
\end{tabular}


Table (3) shows the results of the moderated regression analysis. The results of the analysis indicate that after incorporating the interaction term, i.e. creativity*uncertainty avoidance, the change in $\mathrm{R}^{2}$ is insignificant, at 0.011 . Therefore, as per the findings, uncertainty avoidance does not positively moderate the relationship between creativity and project success, leading to the rejection of hypothesis 5 .

\section{DISCUSSION}

Findings of the current study are in line with the previous literature that Openness to experience predicts creative outcomes and creative processes and likewise, openness to experience is positively associated to project performance in problem solving producing creative ideas (Leung, Maddux, Galinsky \& Chiu, 2008). People scoring high on openness to experience have access to variety of experiences and perspectives therefore it results in creativity in project performance (McCrae \& Costa, 1997). The results of the current study concur that openness to experience is positively associated with the creativity. Therefore, leading to the acceptance of hypothesis one. Reasons for accepting the $\mathrm{H} 1$ according to study are that if employees score high on openness to experience they will be more creative and organizations use creativity of employees to enhance the employee performance, which results in project success. Exploration of ideas is connected with increasing variance, experimentation, searching for alternatives and it is important for organizational learning as well as for the better outcome of project in form of success (March, 1991). Creativity makes employees learn about the fundamental values, identity and motives or goals of the projects (Avolio and Gardner, 2005). Hypothesis two tested that creativity is positively associated with project success, and was accepted, which aligns with the previous studies and the reasons being that exploration of new ideas will help the employee to more creatively enhance theirperformance to achieve the project goals and objectives which leads to project success. Furthermore, rest of the results are also in line with previous literature, Openness to experience has higher connection with project success and its creative achievement for the organization and it also tend to individual differences (Carson, Peterson, \& Higgins, 2005). People who score high on openness to experience are more explorative and have divergent thinking which helps employees to use more creative ideas and outcomes in form of project success (DeYoung, Peterson, \& Higgins, 2005; McCrae, 1987). Openness to experience produces creative processes that increase the organization flexibility and predicts the capacity of individual creativity.

Additionally, creativity makes employees more flexible, they willingly take risks. Openness to experience reduces complexity, which resultantly expands their access to ideas and potential solution for their project success (Gagne' \& Deci, 2005). Mediation hypothesis proposed that creativity mediates the relationship between openness to experience and project success. The results lead to the acceptance of the hypothesis, as supported by the existing literature. As previously established, creativity is viewed as the key to successful implementation of creative ideas by people, who are open to new experiences, thus ultimately leading to the project success (Oldham \& Cummings, 1996). Moderation hypothesis was developed to explore that whether uncertainty avoidance moderates the relationship between creativity and project success or not, i.e. does it strengthens the relationship or not. The rejection of moderation can be justified using context as the base. Pakistan being a predominately uncertainty avoidance culture, at an individual as well as organizational level, may not necessarily mean that it will lead to project success. Employees using creative means, although leading to project success, may take risks by using new methods and new ideas to ensure project success; therefore, rendering to the rejection of moderation hypothesis.

\section{Limitations}

The study like any other attempt as research has certain limitations. The relatively small sample size of just 100 poses as one of the biggest limitation, hampering the generalizability of the findings, across the region. Collecting data from across the country with a larger sample size would not only help overcome the aforesaid limitation, it would provide a clearer and a bigger picture as well.

\section{REFERENCES}

Adams, S. L., \& Anantatmula, V. (2010). Social and behavioral influences on team process. Project Management Journal, 41(4), 89-98.

Albers-Miller, N. D., \& Gelb, B. D. (1996). Business advertising appeals as a mirror of cultural dimensions: A study of eleven countries. Journal of Advertising, 25(4), 57-70.

Alderman, N., \& Ivory, C. (2011). Translation and convergence in projects: An organizational perspective on project success. Project Management Journal, 42(5), 17-30.

Amabile, T. M. (1983). The social psychology of creativity: A componential conceptualization. Journal of Personality and Social Psychology, 45(2), 357. 
Amabile, T. M. (1996). Creativity in context: Update to" the social psychology of creativity.". Westview press.

Andrews, J., \& Smith, D. C. (1996). In search of the marketing imagination: Factors affecting the creativity of marketing programs for mature products. Journal of Marketing Research, 33(2), 174-187.

Avolio, B. J., \& Gardner, W. L. (2005). Authentic leadership development: Getting to the root of positive forms of leadership. The Leadership Quarterly, 16(3), 315-338.

Baccarini, D. (1999). The logical framework method for defining project success. Project Management Journal, 30(4), 25-32.

Bannerman, P. L. (2008, July). Defining project success: a multilevel framework. In Proceedings of the Project Management Institute Research Conference (pp. 1-14).

Barron, F., \& Harrington, D. M. (1981). Creativity, intelligence, and personality. Annual Review of Psychology, 32(1), 439-476.

Burke, L. A., \& Witt, L. A. (2002). Moderators of the openness to experience-performance relationship. Journal of Managerial Psychology, 17(8), 712721.

Cao, Q., \& Hoffman, J. J. (2011). A case study approach for developing a project performance evaluation system. International Journal of Project Management, 29(2), 155-164.

Carson, S. H., Peterson, J. B., \& Higgins, D. M. (2005). Reliability, validity, and factor structure of the creative achievement questionnaire. Creativity Research Journal, 17(1), 37-50.

Chesbrough, H. W. (2006). Open innovation: The new imperative for creating and profiting from technology. Harvard Business Press.

Cicmil, S., \& Hodgson, D. (2006). New possibilities for project management theory: A critical engagement. Project Management Journal, 37(3), 113-128.

Creasy, T., \&Anantatmula, V. S. (2013). From every direction-How personality traits and dimensions of project managers can conceptually affect project success. Project Management Journal, 44(6), 3651 .

Davis, S. A. (2011). Investigating the impact of project managers' emotional intelligence on their interpersonal competence. Project Management Journal, 42(4), 37-57.

DeYoung, C. G., Peterson, J. B., \& Higgins, D. M. (2005). Sources of openness/intellect: Cognitive and neuropsychological correlates of the fifth factor of personality. Journal of Personality, 73(4), 825-858.
Dvir, D., Sadeh, A., \& Malach-Pines, A. (2006). Projects and project managers: The relationship between project managers' personality, project types, and project success. Project Management Quarterly, $37(5), 36$.

Eysenck, H. J. (1995). Creativity as a product of intelligence and personality. In International handbook of personality and intelligence (pp. 231247). Springer US.

Feist, G. J. (1998). A meta-analysis of personality in scientific and artistic creativity. Personality and Social Psychology Review, 2(4), 290-309.

Fredrickson, B. L. (1998). What good are positive emotions?. Review of General Psychology, 2(3), 300 .

Gagné, M., \& Deci, E. L. (2005). Self-determination theory and work motivation. Journal of Organizational Behavior, 26(4), 331-362.

Geoghegan, L., \& Dulewicz, V. (2006). Project Managers' Leadership Competencies and Project Success. WORKING PAPER SERIES-HENLEY MANAGEMENT COLLEGE HWP, 607.

Goldberg, L. R. (1990). An alternative" description of personality": the big-five factor structure. Journal of Personality and Social Psychology, 59(6), 12161229.

Goldsmith, R. E., \& Foxall, G. R. (2003). The measurement of innovativeness. The international handbook on innovation, 321-330.

Gough, H. G. (1979). A creative personality scale for the Adjective Check List. Journal of Personality and Social Psychology, 37(8), 1398-1405.

Heine, S. J., \&Buchtel, E. E. (2009). Personality: The universal and the culturally specific. Annual Review of Psychology, 60, 369-394.

Hofstede, G., Hofstede, G. J., \&Minkov, M. (1991). Cultures and organizations: Software of the mind (Vol. 2), p5. London: McGraw-Hill.

Hyvonen, S., \& Tuominen, M. (2006). Entrepreneurial innovations, market-driven intangibles and learning orientation: critical indicators for performance advantages in SMEs. International Journal of Management and Decision Making, 7(6), 643-660.

Ika, L. A. (2009). Project success as a topic in project management journals. Project Management Journal, 40(4), 6-19.

Jugdev, K., \& Müller, R. (2005). A retrospective look at our evolving understanding of project success. Project Management Journal, 36(4), 19-31.

Jugdev, K., Thomas, J., \& Delisle, C. (2001). Rethinking project management: old truths and new insights. International Project Management Journal, 7(1), 36-43.

Leung, A. K. Y., Maddux, W. W., Galinsky, A. D., 
\& Chiu, C. Y. (2008). Multicultural experience enhances creativity: the when and how. American Psychologist, 63(3), 169-181.

March, J. G. (1991). Exploration and exploitation in organizational learning. Organization Science, 2(1), 71-87.

McCrae, R. R., \& Costa Jr, P. T. (1997). Personality trait structure as a human universal. American Psychologist, 52(5), 509-516.

McCrae, R. R., \& Costa, P. T. (1987). Validation of the five-factor model of personality across instruments and observers. Journal of Personality and Social Psychology, 52(1), 81-90.

McCrae, R. R., \& John, O. P. (1992). An introduction to the five-factor model and its applications. Journal of Personality, 60(2), 175-215.

Mohrman, S. A., Gibson, C. B., \&Mohrman, A. M. (2001). Doing research that is useful to practice a model and empirical exploration. Academy of Management Journal, 44(2), 357-375.

Oldham, G. R., \& Cummings, A. (1996). Employee creativity: Personal and contextual factors at work. Academy of management journal, 39(3), 607-634.

Packendorff, J. (1995). Inquiring into the temporary organization: new directions forprojectmanagement research. Scandinavian Journal of Management, 11(4), 319-333.

Parker, S. K., \& Axtell, C. M. (2001). Seeing another viewpoint: Antecedents and outcomes of employee perspective taking. Academy of Management Journal, 44(6), 1085-1100.

Pinto, J. K., \&Slevin, D. P. (1988). Project success: definitions and measurement techniques. Project Management Institute.

Pulver, A., Allik, J., Pulkkinen, L., \& Hämäläinen, M. (1995). A Big Five personality inventory in two non-Indo-European languages. European Journal of Personality, 9(2), 109-124.

Salgado, J. F. (1997). The Five Factor Model of personality and job performance in the European Community. Journal of Applied Psychology, 82(1), 30-43.

Salge, T. O., Farchi, T., Barrett, M. I., \& Dopson, S. (2013). When Does Search Openness Really Matter? A Contingency Study of Health-Care Innovation Projects. Journal of Product Innovation Management, 30(4), 659-676.

Shalley C (eds) Handbook of Organizational Creativity. New York, NY: Lawrence Erlbaum

Shalley C and Zhou J (2008) Organizational creativity research: A historical overview.
Shenhar, A. J., Dvir, D., Levy, O., \& Maltz, A. C. (2001). Project success: a multidimensional strategic concept. Long Range Planning, 34(6), 699-725.

Singelis, T. M. (1994). The measurement of independent and interdependent self-construals. Personality and Social Psychology Bulletin, 20(5), 580-591.

Skulmoski, G. J., \& Hartman, F. T. (2010). Information systems project manager soft competencies: A project-phase investigation. Project Management Journal, 41(1), 61-80

Staw, B. M. (1995). Why no one really wants creativity. Creative action in organizations, 161-66.

Steenkamp, J. B. E., Hofstede, F. T., \& Wedel, M. (1999). A cross-national investigation into the individual and national cultural antecedents of consumer innovativeness. The Journal of Marketing, 63(2), 55-69.

Thal Jr, A. E., \& Bedingfield, J. D. (2010). Successful project managers: an exploratory study into the impact of personality. Technology Analysis \& Strategic Management, 22(2), 243-259.

Thomas, G., \&Fernández, W. (2008). Success in IT projects: A matter of definition?. International Journal of Project Management, 26(7), 733-742.

Triandis, H. C. (1996). The psychological measurement of cultural syndromes. American Psychologist, 51(4), 407-415.

Wanberg, C.R.Banas, J.T. (2000). Predictors and outcomes and openness to change at organizing workplace, Journal of Applied Psychology, 85(1), 132-142.

Woodman, R. W., Sawyer, J. E., \& Griffin, R. W. (1993). Toward a theory of organizational creativity. Academy of management review, 18(2), 293-321.

Yang, T., \& Chen, C. W. (2009). An incentive pay system for project management based on responsibility assignment matrix and fuzzy linguistic variables. Expert Systems with Applications, 36(10), 1258512591.

Zhou, J. (2003). When the presence of creative coworkers is related to creativity: role of supervisor close monitoring, developmental feedback, and creative personality. Journal of Applied Psychology, 88(3), 413-422.

Zhou, J., \&Shalley, C. E. (2003). Research on employee creativity: A critical review and directions for future research. Research in Personnel and Human Resources Management, 22, 165-218.

Zqikael, O., Levin, G., \& Rad, P. F. (2008). Top Management Support: The Project Friendly Organization. Cost Engineering, 50(9), 22-30. 